\title{
Personalized genetic testing and norovirus susceptibility
}

\author{
Natalie Prystajecky $\mathrm{PhD}^{1,2}$, Fiona SL Brinkman $\mathrm{PhD}^{3}$, Brian Auk BSc${ }^{1}$, \\ Judith L Isaac-Renton MD DPH FRCPC ${ }^{1,2}$, Patrick Tang MD PhD FRCPC ${ }^{1,2}$
}

\begin{abstract}
N Prystajecky, FSL Brinkman, B Auk, JL Isaac-Renton,
$P$ Tang. Personalized genetic testing and norovirus susceptibility. Can J Infect Dis Med Microbiol 2014;25(4):222-224.
\end{abstract}

BACKGROUND: The availability of direct-to-consumer personalized genetic testing has enabled the public to access and interpret their own genetic information. Various genetic traits can be determined including resistance to norovirus through a nonsense mutation (G428A) in the FUT2 gene. Although this trait is believed to confer resistance to the most dominant norovirus genotype (GII.4), the spectrum of resistance to other norovirus strains is unknown. The present report describes a cluster of symptomatic norovirus GI.6 infection in a family identified to have norovirus resistance through personalized genetic testing.

CASE PRESENTATION: In January 2013, four members of a family determined by a direct-to-consumer genetic test to be homozygous for the norovirus resistance trait (A/A genotype for single nucleotide polymorphism rs601338) developed symptoms consistent with acute viral gastroenteritis. Stool and vomitus samples were submitted for enteric viral pathogen testing. Samples were positive for norovirus GI.6 in three of the four cases.

CONCLUSIONS: The present report is the first to describe norovirus GI.6 infection in patients with the G428A nonsense mutation in FUT2; this cluster of cases suggests that the G428A mutation in FUT2 may not confer resistance to norovirus GI.6. Direct-toconsumer genetic testing is empowering members of the public to identify novel associations with their genetic traits. Expert consultation is important for the interpretation of personalized genetic test results, and follow-up laboratory testing can confirm any potentially novel associations.

Key Words: Direct-to-consumer genetic testing; Norovirus; Norovirus resistance

Worldwide, norovirus is the most common cause of acute viral gastroenteritis in adults (1). Multiple host and viral factors contribute to the persistence of noroviruses in the human population, including the environmental stability of the virus, resistance to some disinfecting agents, low infectious dose and postinfection shedding, lack of long-term cross-protective immunity after infection and frequent replacement of the predominant circulating strain due to the existence of multiple genotypes and strains, and antigenic drift (2-5). Noroviruses are spread predominantly through the fecal-oral route, but aerosolization through vomitus is another possible route of transmission (6). The rates of norovirus infection follow a seasonal pattern, with higher rates during winter months in temperate regions (7). In addition to numerous sporadic cases in the community, outbreaks are commonly reported in many public settings including

\section{Les tests génétiques personnalisés et la susceptibilité au norovirus}

HISTORIQUE : Les tests génétiques personnalisés destinés directement aux consommateurs permettent au public d'accéder eux-mêmes à l'information génétique et à l'interpréter. Il est ainsi possible de déterminer divers traits génétiques, y compris la résistance au norovirus par une mutation non-sens (G428A) dans le gène FUT2. Même si on pense que ce trait confère une résistance au génotype du norovirus le plus dominant (GII.4), on n'en connaît pas le spectre de résistance à d'autres souches de norovirus. Le présent rapport décrit une grappe d'infection symptomatique au norovirus GI.6 au sein d'une famille dont la résistance au norovirus avait été établie au moyen de tests génétiques personnalisés.

PRÉSENTATION DU CAS : En janvier 2013, quatre membres d'une famille qui, d'après un test génétique destiné directement au consommateur, étaient homozygotes au trait de résistance au norovirus (génotype A/A du polymorphisme de nucléotide simple rs601338) ont présenté des symptômes évocateurs d'une gastroentérite virale aiguë. Des coprocultures et des prélèvements de vomissures ont été soumis à un test pour déceler un virus entéropathogène. Dans trois des quatre cas, les prélèvements étaient positifs au norovirus GI.6.

CONCLUSIONS : Le présent rapport est le premier à décrire l'infection à norovirus GI.6 chez des patients présentant la mutation non-sens G428A dans le gène FUT2. Ce groupe de cas laisse croire que la mutation G428A dans le gène FUT2 ne confère pas de résistance au norovirus GI.6. Les tests génétiques destinés directement aux consommateurs permettent aux membres du public d'établir de nouvelles associations avec leurs traits génétiques. Il est important de consulter un expert pour en interpréter les résultats, et des tests de laboratoire effectués en suivi peuvent confirmer ces associations potentielles.

\footnotetext{
${ }^{1}$ British Columbia Public Health Microbiology and Reference Laboratory, Provincial Health Services Authority; ${ }^{2}$ Department of Pathology and Laboratory Medicine, University of British Columbia, Vancouver; ${ }^{3}$ Department of Molecular Biology and Biochemistry, Simon Fraser University, Burnaby, British Columbia

Correspondence: Dr Patrick Tang, British Columbia Public Health Microbiology and Reference Laboratory, British Columbia Centre for Disease Control, 655 West 12th Avenue, Vancouver, British Columbia V5Z 4R4. Telephone 604-707-2616, fax 604-707-2675, e-mail patrick.tang@bccdc.ca
} 
also play a role in host susceptibility to noroviruses. In particular, secretor status or the ability to express histo-blood group antigens on mucosa is likely correlated with the risk of developing symptomatic norovirus infection. Most GII.4 and some GI.1 (Norwalk virus) noroviruses have been shown to require binding to histo-blood group antigens and, thus, nonsecretors are believed to be resistant to infection by these genotypes $(12,13)$. One of the common mutations affecting secretor status is the G428A nonsense mutation in the FUT2 gene, which encodes for the fucosyltransferase-2 enzyme (14-16). Individuals who are homozygous for the G428A mutation in FUT2 are nonsecretors. In clinical studies, it has been shown that these individuals are resistant to symptomatic infection by norovirus GI.1 (15) and most GII.4 strains $(17,18)$. In one reported outbreak of norovirus GI.3, nonsecretor status was not protective against norovirus infection (19). The full extent of the norovirus resistance that is conferred by the G428A mutation against different genotypes and strains of norovirus is not currently known.

The introduction of direct-to-consumer genetic testing has enabled the public to examine their own genetic traits and ancestry. While there is ongoing debate regarding whether these tests require the same regulatory oversight as other medical tests, hundreds of thousands of consumers have undergone these tests and, in some cases, they are using the test results to change health behaviours and even alerting their physicians to the results (20). These tests allow the public to potentially identify novel genetic associations at the individual and family level, and some test providers even allow customers to crowdsource and conduct their own community-based genetic research. One company alone, 23andMe (USA), has currently tested close to 500,000 individuals, creating a large genetic database with the potential to make valuable discoveries $(21,22)$. These tests are most useful for the determination of monogenic traits such as secretor status. We describe a cluster of norovirus GI.6 in four family members that was identified by direct-to-consumer genetic testing as being homozygous for the G428A mutation in FUT2.

\section{CASE PRESENTATION}

A family in British Columbia had undergone genetic testing through 23 andMe and all four individuals were determined to be "norovirus resistant" (A/A genotype for SNP rs601338). During the 2012-2013 norovirus season, all the family members developed an illness consistent with viral gastroenteritis. The index case (patient A) was a sixyear-old girl who presented with nausea, vomiting and diarrhea. On day 2, the mother of the index case (patient B, a 46-year-old woman) presented with nausea and mild diarrhea, but did not experience any vomiting. On day 3, the 10-year-old brother of the index case (patient C) developed symptoms of nausea, vomiting and diarrhea. Later on day 3 , the father of the index case (patient D, a 46-year-old man) also developed nausea, vomiting and diarrhea. There were no other people living within the household. All members of the family cluster resolved their symptoms within two days of illness onset without medical intervention. On day 3, stool samples were collected from patients A, B and D and a vomitus sample was collected from patient C. On day 4 , samples were submitted for enteric virus testing.

Two of the three stool samples (patients A and D) and the vomitus sample (patient C) tested positive for norovirus genogroup I by reverse-transcriptase polymerase chain reaction. Total nucleic acid was extracted from stool and vomitus using NucliSENS easyMag (bioMerieux, USA) and tested in a duplex real-time reverse-transcriptase polymerase chain reaction targeting norovirus genogroups I and II (23). Sequencing of the capsid VP1 region (region C) determined that these noroviruses belonged to genotype GI.6 (Genbank accession numbers KJ569103-5) (24). Norovirus outbreak surveillance for British Columbia showed that 20\% of gastroenteritis outbreaks reported to the British Columbia Public Health Microbiology and Reference Laboratory were due to norovirus GI.6 during the 20122013 norovirus season (25). This is significantly higher than in the previous norovirus season (0\% detected in 2011-2012). An increased incidence of norovirus GI.6 in 2012 was also reported in Alberta and in the United States $(26,27)$.

\section{CONCLUSIONS}

Direct-to-consumer genetic testing has the potential to increase public awareness of genetically determined traits such as disease risk and response to drugs. However, genetic information can also be misinterpreted without an overall understanding of the clinical and scientific knowledge associated with these genetic traits. Many phenotypes are determined by multiple genes or by a complex combination of genetic, environmental and other factors. Currently, the most popular directto-consumer genetic tests target single nucleotide polymorphisms (SNPs) found throughout the human genome. These SNP-based tests are most useful for genetic traits that are monogenic (or mostly monogenic). Results from these tests are often relayed to the consumers through a website rather than through a health care professional with expertise in medical genetics.

The 23andMe online report for norovirus resistance explains that this trait is highly heritable. Individuals with two copies of the 'A' SNP (G428A) are "resistant to infection by the most common strain of norovirus". The website also explains that there may be other genetic determinants of norovirus resistance that may confer resistance in those who do not have the 'AA' genotype. Individuals who are not familiar with the diversity of norovirus genotypes and strains may not understand that norovirus resistance from the G428A mutation may not protect them from all norovirus infections. Furthermore, for genetic traits associated with resistance or susceptibility to infectious agents, it is important that genetic test vendors update their databases frequently to reflect the rapid evolution and strain replacements associated with infectious agents. Consumers should be informed that new information may lag behind the emergence of new strains and variants.

Conversely, some individuals, including those with more knowledge, may be able to use such genetic information to aid identification of previously unappreciated disease susceptibility and other novel associations with genetic traits. In the present report, we show that norovirus GI.6 was able to cause symptomatic infection in four individuals who were determined to be homozygous for the G428A mutation in FUT2 through direct-to-consumer genetic tests, including two adults with different genetic backgrounds. Although we were unable to perform independent confirmation of the G428A mutation, it is unlikely that the SNP would be incorrectly assigned in all four individuals because the concordance of direct-to-consumer genetic testing is high $(>99.6 \%)$ and the homozygous mutation in the children matched that of the parents (28). While we issue caution on the interpretation of direct-to-consumer genetic testing results and the need for expert consultation, we also demonstrate the potential of these tests to allow individuals to accelerate the process of identifying new associations between host genetic traits and phenotypes.

DISCLOSURES: The authors have no conflicts of interest to declare.

AUTHORS' CONTRIBUTIONS: PT and FB collected the clinical and genetic data. NP, BA and JIR analyzed the norovirus genotyping results. NP and PT drafted the manuscript. All authors have read, edited and approved the manuscript.

ACKNOWLEDGEMENTS: The authors thank the Environmental Microbiology Section at the British Columbia Public Health Microbiology and Reference Laboratory for performing the norovirus laboratory testing.

\section{REFERENCES}

1. Patel MM, Widdowson MA, Glass RI, Akazawa K, Vinje J,

Parashar UD. Systematic literature review of role of noroviruses in sporadic gastroenteritis. Emerg Infect Dis 2008;14:1224-31.

2. Patel MM, Hall AJ, Vinje J, Parashar UD. Noroviruses:

A comprehensive review. J Clin Virol 2009;44:1-8. 
3. Tung G, Macinga D, Arbogast J, Jaykus LA. Efficacy of commonly used disinfectants for inactivation of human noroviruses and their surrogates. J Food Prot 2013;76:1210-7.

4. Donaldson EF, Lindesmith LC, Lobue AD, Baric RS. Viral shapeshifting: Norovirus evasion of the human immune system. Nat Rev Microbiol 2010;8:231-41.

5. Bull RA, Tu ET, McIver CJ, Rawlinson WD, White PA. Emergence of a new norovirus genotype II.4 variant associated with global outbreaks of gastroenteritis. J Clin Microbiol 2006;44:327-33.

6. Chadwick PR, McCann R. Transmission of a small round structured virus by vomiting during a hospital outbreak of gastroenteritis. J Hosp Infect 1994;26:251-9.

7. Ahmed SM, Lopman BA, Levy K. A systematic review and metaanalysis of the global seasonality of norovirus. PLoS One 2013;8:e75922.

8. Xi JN, Graham DY, Wang KN, Estes MK. Norwalk virus genome cloning and characterization. Science 1990;250:1580-3.

9. Kroneman A, Vega E, Vennema H, et al. Proposal for a unified norovirus nomenclature and genotyping. Arch Virol 2013;158:2059-68.

10. Zheng DP, Ando T, Fankhauser RL, Beard RS, Glass RI, Monroe SS. Norovirus classification and proposed strain nomenclature. Virology 2006;346:312-23.

11. Siebenga JJ, Vennema H, Zheng DP, et al. Norovirus illness is a global problem: Emergence and spread of norovirus GII.4 variants, 2001-2007. J Infect Dis 2009;200:802-12.

12. Hutson AM, Atmar RL, Graham DY, Estes MK. Norwalk virus infection and disease is associated with $\mathrm{ABO}$ histo-blood group type. J Infect Dis 2002;185:1335-7.

13. Marionneau S, Ruvoen N, Le Moullac-Vaidye B, et al. Norwalk virus binds to histo-blood group antigens present on gastroduodenal epithelial cells of secretor individuals. Gastroenterology 2002;122:1967-77.

14. Le Pendu J, Ruvoen-Clouet N, Kindberg E, Svensson L. Mendelian resistance to human norovirus infections. Semin Immunol 2006;18:375-86.

15. Lindesmith L, Moe C, Marionneau S, et al. Human susceptibility and resistance to Norwalk virus infection. Nat Med 2003;9:548-53.

16. Thorven M, Grahn A, Hedlund KO, et al. A homozygous nonsense mutation $(428 \mathrm{G}->A)$ in the human secretor (FUT2) gene provides resistance to symptomatic norovirus (GGII) infections. J Virol 2005;79:15351-5.

17. Carlsson B, Kindberg E, Buesa J, et al. The G428A nonsense mutation in FUT2 provides strong but not absolute protection against symptomatic GII.4 Norovirus infection. PloS One 2009;4:e5593.

18. de Rougemont A, Ruvoen-Clouet N, Simon B, et al. Qualitative and quantitative analysis of the binding of GII.4 norovirus variants onto human blood group antigens. J Virol 2011;85:4057-70.

19. Nordgren J, Kindberg E, Lindgren PE, Matussek A, Svensson L. Norovirus gastroenteritis outbreak with a secretor-independent susceptibility pattern, Sweden. Emerg Infect Dis 2009;16:81-7.

20. Green RC, Farahany NA. Regulation: The FDA is overcautious on consumer genomics. Nature 2014;505:286-7.

21. Hinds DA, McMahon G, Kiefer AK, et al. A genome-wide association meta-analysis of self-reported allergy identifies shared and allergy-specific susceptibility loci. Nat Genet 2013;45:907-11.

22. Lill CM, Roehr JT, McQueen MB, et al. Comprehensive research synopsis and systematic meta-analyses in Parkinson's disease genetics: The PDGene database. PLoS Genet 2012;8:e1002548.

23. Kageyama T, Kojima S, Shinohara M, et al. Broadly reactive and highly sensitive assay for Norwalk-like viruses based on real-time quantitative reverse transcription-PCR. J Clin Microbiol 2003;41:1548-57.

24. Kojima S, Kageyama T, Fukushi S, et al. Genogroup-specific PCR primers for detection of Norwalk-like viruses. J Virol Methods 2002;100:107-14.

25. British Columbia Public Health Microbiology and Reference Laboratory. Laboratory Trends. January 4, 2013. <www.bccdc.ca/ NR/rdonlyres/4EB32484-4C02-4E68-B2F2-CB88089CF7FD/0/ Jan2013LaboratoryTrends.pdf> (Accessed May 2014).

26. Leshem E, Barclay L, Wikswo M, et al. Genotype GI.6 norovirus, United States, 2010-2012. Emerg Infect Dis 201319:1317-20.

27. Hasing ME, Lee BE, Preiksaitis JK, et al. Emergence of a new norovirus GII.4 variant and changes in the historical biennial pattern of norovirus outbreak activity in Alberta, Canada, from 2008 to 2013. J Clin Microbiol 2013;51:2204-11.

28. Imai K, Kricka LJ, Fortina P. Concordance study of 3 direct-toconsumer genetic-testing services. Clin Chem 2011;57:518-21. 


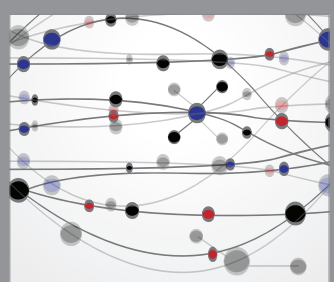

The Scientific World Journal
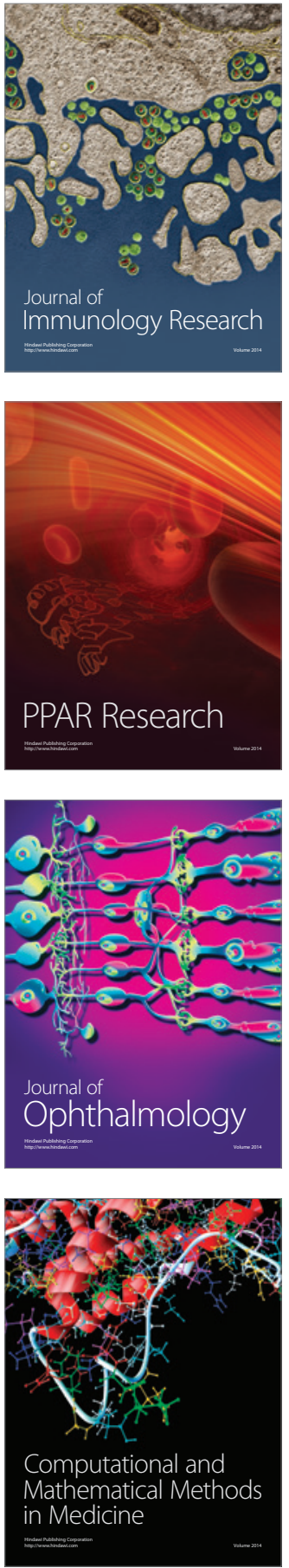

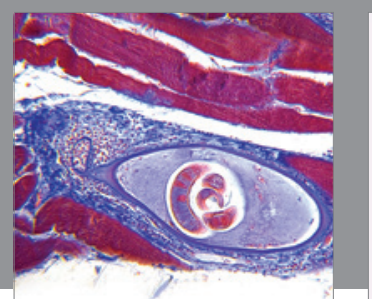

Gastroenterology Research and Practice

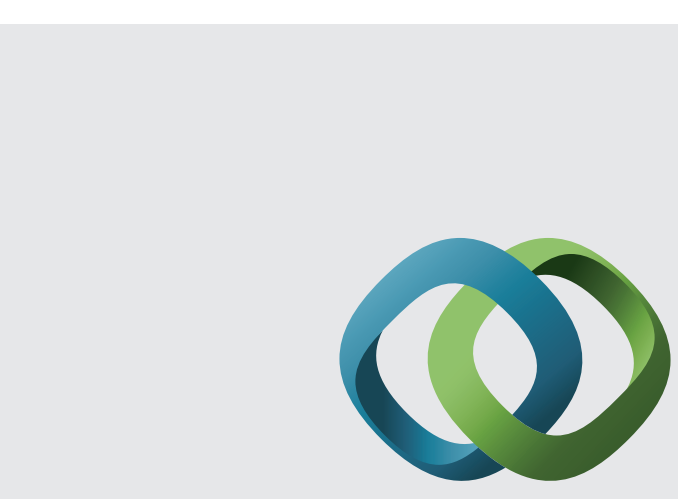

\section{Hindawi}

Submit your manuscripts at

http://www.hindawi.com
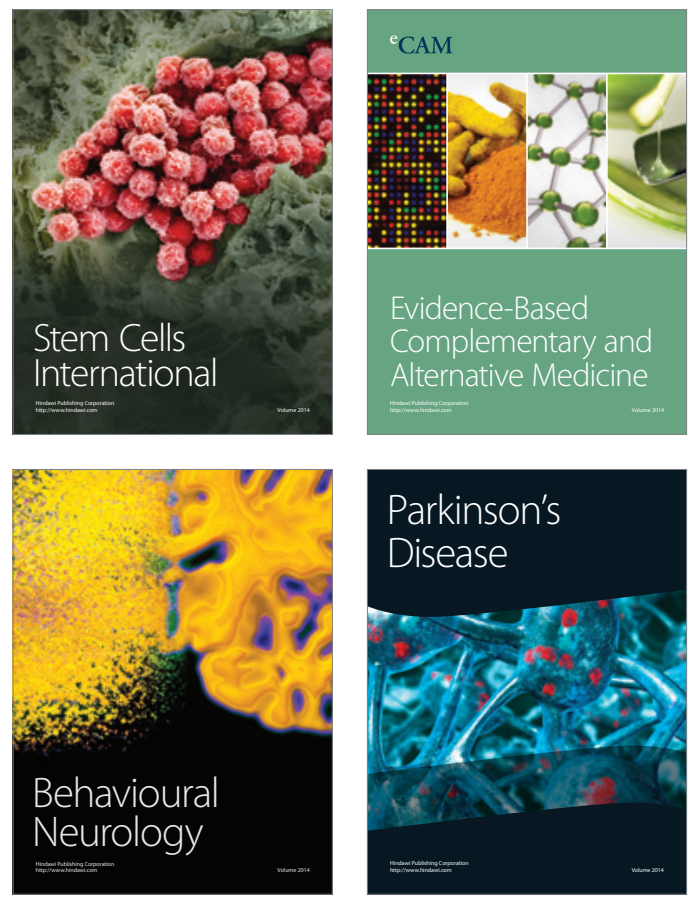
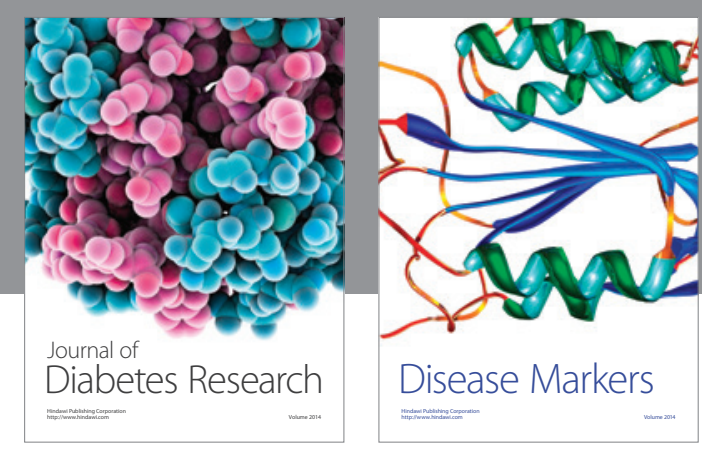

Disease Markers
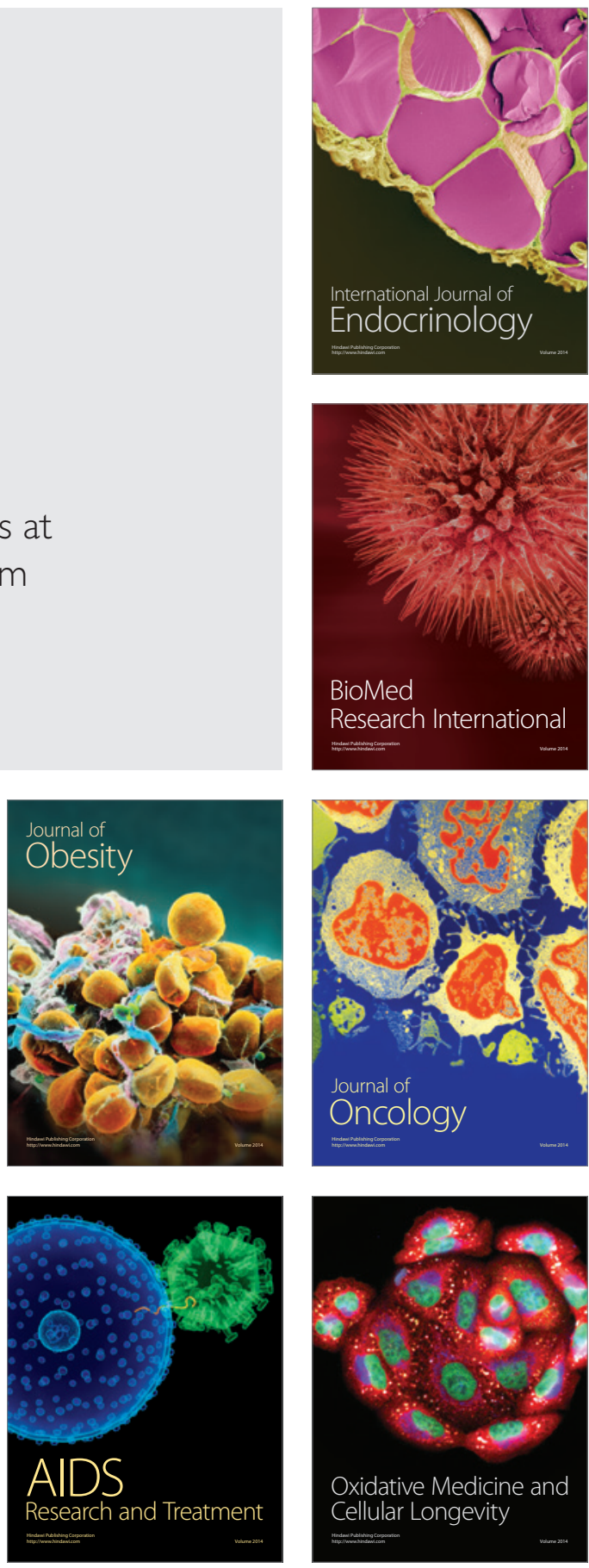